\title{
Physical Test Training as a Part of Preventive Health Equipment Maintenance in Puskesmas Ciledug, Tangerang City
}

\author{
Frisa Yugi Hermawan ${ }^{1 *}$ iD \\ ${ }^{1}$ Health Polytechnic of the Ministry of Health Jakarta II, Indonesia \\ *Corresponding author: hermawan1234@gmail.com
}

\begin{abstract}
Health equipment is one of the most important supporting factors in the implementation of health services in health service facilities. The condition and function of health equipment must be good and can support health services. The Ciledug Public Health Center (Puskesmas Ciledug) in Tangerang City has an electromedical device that requires regular maintenance. This activity aimed to provide a correct understanding of the inspection and preventive maintenance (IPM) of electromedical devices to operators/users in the electrical sector, which was oriented towards habits (routine) as a preventive activity before the equipment is damaged and can extend the life of the electromedical device. The used methods were presentation, discussion, practice, and functional tests to the devices. The expected results were to be input to improve the ability of users/operators in handling IPM and build an understanding related to a culture of caring for maintenance to the top Management of Puskesmas Ciledug.
\end{abstract}

Keywords: Health Centers, Medical Equipment, Inspection, Preventive Maintenance, Function Test, Performance Test

\section{Introduction}

Puskesmas is a functional health organization. It is central to the development of public health that fosters community participation and provides comprehensive services and integrated. Puskesmas has main activities that must be carried out by the Government to create community welfare.(Kemenkes, 2019; kementerian Kesehatan, 2014; Ministry of Health, 2019; Wikipedia, 2014) The main goal of Puskesmas are to support the achievement of national health development goals, namely increasing awareness, willingness, and the ability to live healthy for every person residing in the working area of the Puskesmas to achieve the highest health standard.

Puskesmas is a health technical implementation unit under the supervision of the District/City Health Office. In general, Puskesmas must provide preventive, promotive, curative, and rehabilitative services, either through individual health efforts (UKP) or community health efforts (UKM). Puskesmas can provide inpatient services besides outpatient services. Puskesmas usually has sub-unit services such as auxiliary health centers, mobile health centers, Posyandu, village health posts, and village maternity posts (Polindes).

The working area of Puskesmas covers one sub-district or part of a sub-district. The factors of population density, area size, geographical conditions, and other infrastructure conditions are considered in determining the working area of the Puskesmas. Puskesmas is a 2nd level apparatus of the Regional Government so that the division of work areas for the

\begin{tabular}{|c|c|c|}
\hline History: & & Publisher: Undiksha Press \\
\hline Received & : 02 August 2020 & Licensed: This work is licensed under \\
\hline Revised & : 09 September 2020 & a Creative Commons Attribution 3.0 License \\
\hline Accepted & : 06 October 2020 & (c) (†) (?) \\
\hline Published & : 30 November 2020 & \\
\hline
\end{tabular}


Puskesmas is determined by the Regent or Mayor, with technical advice from the head of the Regency / City Health Office.

As a referral center for village health centers and also has a coordination function. Health services provided by Puskesmas are comprehensive health services which include Curative (treatment), Preventive (preventive measures), Promotive (health improvement), Rehabilitative (health restoration). The Puskesmas functions are; As the Center for Community Health Development in its working area. Fostering community participation in the working area to improve the ability to live healthily. Provide comprehensive and integrated health services to the community in the working area.

In the Regional Autonomy context, Puskesmas has a very vital role as a technical implementing institution that is required to have managerial capabilities and foresight to improve the quality of health services. Thus the availability of health equipment will determine the implementation of optimal, effective, and efficient health services at Puskesmas. This Puskesmas equipment includes medical and non-medical equipment needed to carry out efforts or service activities inside and outside the Puskesmas building and its network includes community-based health service facilities or UKBM.

In fact, for medical equipment, Puskesmas pay less attention and meet the accuracy of the equipment, especially in carrying out periodic maintenance that must be carried out at a certain period. The condition and function of health equipment must be good and can support these health services. To achieve this condition, it is necessary to have good and integrated equipment management from planning, procurement, utilization to maintenance. Therefore health equipment and supporting facilities will be optimally effective in the implementation of health services. Maintenance of medical equipment is an important function to create a satisfactory condition by the plan and to keep being good as long as they were used before a certain planned period was reached.(GA. Bassett, 1971; IKATEMI, 2015; Margono, 2006; Ministry of Health, 2011, 2019; Permenkes, 2016)

Puskesmas Ciledug, Tangerang city located at Jl. KH Hasyim Ashari No. 2 Ciledug Tangerang Banten. The profile of the Ciledug sub-district is as follows includes 8 number of urban villages: West Sudimara (Postcode: 15151), Sudimara Jaya Sub-district (Kodepos: 15151), South Sudimara Sub-District / (Kodepos: 15151), East Sudimara Sub-district ( Postcode: 15151), Tajur Sub-district (Postcode: 15152), Paninggilan Sub-district (Postcode: 15153), Paninggilan Utara Sub-district (Kodepos: 15153), Parung Serab Sub-district (Postcode: 15153). Total area: $8.73 \mathrm{~km}^{2}$, Total population: 142,541, number of RW: 102, number of RT: 363.The Top 10 numbers of major diseases that occurred in the Ciledug subdistrict in are Acute Nasopharyngitis, Pulp necrosis, Dermatitis, Infection Acute Upper Airway, Influenza, virus not identified, Essential Hypertension, Cough, Headache, Gastritis and Duodenitis, Myalgia. Figure 1 shows the Location via Google Maps.

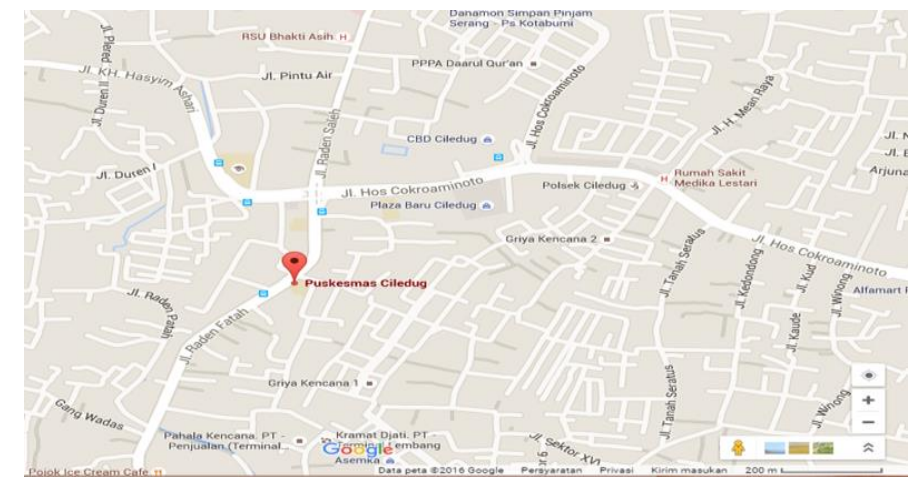

Figure 1. Puskesmas Ciledug Location by Google Maps 
According to The American Management Association, Inc. (1971), Maintenance is a routine activity to maintain the equipment condition as its actual function and capacity efficiently. Different from repair maintenance is also defined as a combination of various actions taken to maintain an item or repair it to an acceptable condition. Medical Devices will be more cared for only during procurement and when they experience problems/damage. Preventive inspections and maintenance of medical equipment are still considered unnecessary. Most of the health service units only provide funds for equipment repairs which from year to year with the value of repairs always increases sharply. This is our reason to take the theme of inspection and preventive maintenance as community service activities to fulfill the rights of health equipment, which include the right to get a preventive inspection and maintenance program in addition to calibration, service, and the availability of funds for the program. Preventive inspection and maintenance activities are mandatory activities for which the implementation activities need to be scheduled. Inspection and preventive maintenance are not only the responsibility of technicians but operators/users have a major contribution to these activities which of course are still based on their authority, especially in terms of electricity.(Arillia Pitaloka Kurniasih, 2010; Berkah Mulia Group, 2016; DPR RI, 2009; Dunia Listrik, 2010; GA. Bassett, 1971; Hartoyo, 1996; Kesehatan \& Indonesia, 2011; Margono, 2006; Ministry of Health, 2011, 2019; Rahmad Azly, 2016; SCORE, 2013; Sekretariat Departemen Energi dan Sumber Daya Mineral, 2009; Swaraswardiyono, 2016) The benefit of it is trained personnel who can carry out regular maintenance programs.

The Health Polytechnic of the Ministry of Health, Jakarta II, is an educational institution for health workers whose tasks are not only through continuous improvement of the quality of learning in the classroom, but also the quality of learning in laboratories, in practice fields in various health service settings, and the community. One of the activities of the Health Polytechnic Jakarta II Health Polytechnic Education Program, which is related to the Tri Darma of Higher Education, is community service for lecturers and students. This community service activity aims to increase the user's ability to carry out preventive maintenance in terms of electromedical devices.(Kesehatan \& Indonesia, 2011; Rahmad Azly, 2016)

The benefits of this Community Service activity are the maintenance of health equipment as a means of health services at the Ciledug Community Health Center in Tangerang City and increasing knowledge and skills for users in terms of preventive maintenance at Ciledug Health Center, Tangerang city. For educational institutions, it is the improvement of professional skills for lecturers in terms of inspection and preventive maintenance of medical equipment.

\section{Materials and Methods}

At this stage, the preparation is in the form of a survey. The team was coming to greeted by the Head of Puskesmas Ciledug Puskesmas Ciledug. In this first survey, it was a preamble for me and the PKM TEAM to introduce themselves and state the aims and objectives of this PKM activity. There is also an agenda to find out: Number of patients per day, Number of Puskesmas staff, The area of land and building of the Puskesmas. My second arrival and the PKM TEAM were welcomed by Mr. Lutfi, a Puskesmas employee who is delegated by the head of the Puskesmas to handle health equipment at the Puskesmas. On this occasion, the PKM TEAM and I set out to ask: Number and specifications of existing medical devices, Flow and process of procurement of equipment to the removal of medical devices, Responsible for the condition and completeness of the medical equipment.

The health center's condition survey is related to the management of electromedical equipment to obtain the condition of its management personnel, electromedical equipment, IPM procedures, and maintenance schedules. This data will be used to determine the material 
for improving human resource capabilities in implementation. Besides, they are trained to modify the mandatory IPM work for each piece of equipment based on the availability of available sources and compile an IPM schedule for each Puskesmas. Stages This stage is a follow-up to the preparation stage. At this stage, the assessment is carried out after all data and statements have been obtained. The study carried out was to formulate problems and topics following this PKM activity. The results of the assessment are about the safety of electric power. This topic arises due to a mismatch between the conditions of the electrical installation at the health center and the Ministry of Health standards. At the planning stage, the theme of electric power safety is being put forward for counseling and physical testing at the Ciledug Community Health Center. At the planning stage, material collection and presentation slides are made to be displayed during the program implementation. Apart from that, there is also a mapping of the Puskesmas rooms which can be turned into real cases in the field.

\section{Results and Discussion}

The implementation of this PKM activity was carried out began with an opening and remarks from the head of the Ciledug Community Health Center PKM Team and the head of the Ciledug Community Health Center. After that, it was followed by the presentation of counseling materials, including the presentation of electricity safety material. After the presentation of the material, it was followed by a discussion session and a question and answer session regarding the actual conditions that occurred at the Ciledug Community Health Center. From these results, it is followed up with the direct observation of the actual condition of the mismatch between the guidelines and the presentation presented with the conditions in the Puskesmas. The training will be conducted on the Physical Test of medical devices with the methods used: Lecture method, which is used to describe the material that has been prepared by the Implementation Team. Question and answer method, which is used to respond to the level of understanding of what the socialization participants have conveyed by the Implementing Team. The method of discussion, in which the presenters and participants hold a dialogue discussing issues around the inspection and maintenance of medical equipment and occupational safety as well as the use of safe medical equipment. Figures 2 shows the used methods in this activity.

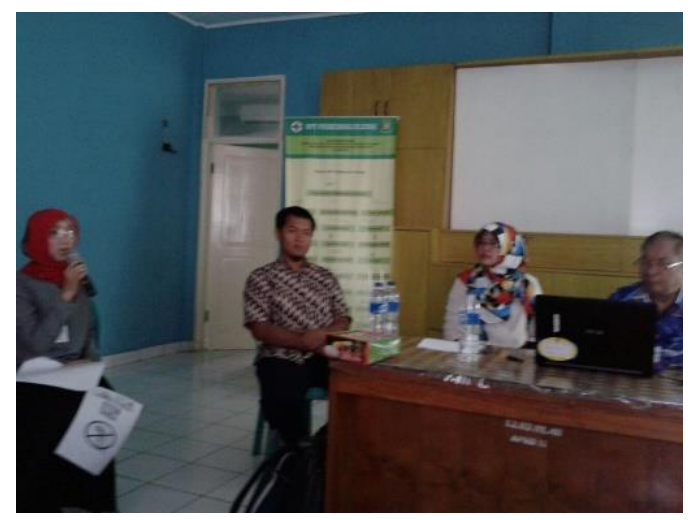

Figures 2. The Activity while Presenting the Presentation.

At this stage, the results of what should be done to be repaired and what should be accepted are carried out for the conditions given by the Tangerang City health office. It can be concluded and evaluated that: The use of sockets should not be in tight connections (multiple connections at one socket point). It is necessary to rearrange the socket points to 
avoid the reach of small children. It is necessary to carry out independent evaluations and routine checks by health center staff on the electrical wiring regarding the installation and quality of the Puskesmas electrical system, as well as the electrical system for medical equipment. Electricity safety is also an aspect that needs to be considered to avoid negligence, work accidents, fires, and death.

The condition of electric power safety at the Ciledug Community Health Center, Tangerang City, Banten Province is already good. The installation conditions in each room are quite neat. An outlet point can be found in every room, but it is still not sufficient for the need for an electrical connection. The thing that is concerning about the power condition of this Puskesmas is the lack of value for the power required. For the required power capacity, it should be immediately submitted to the relevant agency, because the minimum standard of electric power at the health center is 2200VA. To meet the increase in connection points in sockets, it is better to add more socket points by taking into account the type and diameter of the cable. Figure 3 shows the needed electrical socket for the room.

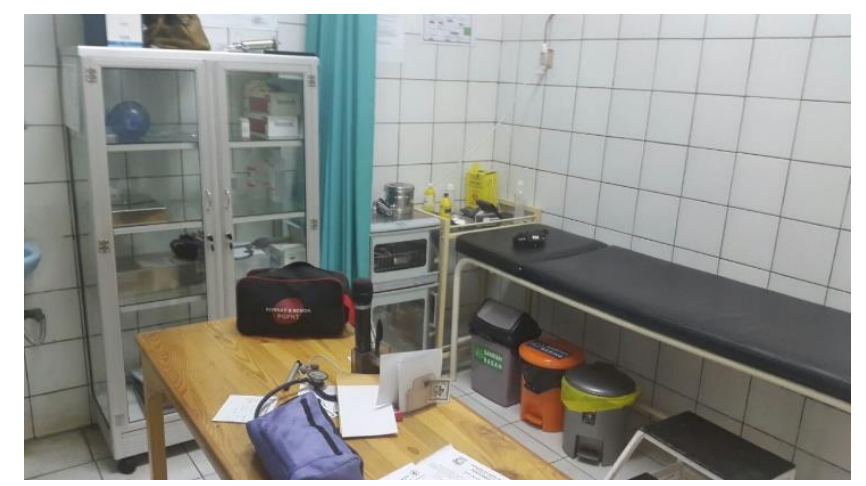

Figure 3. The Deeded Electrical Socket for The Room.

\section{Conclusion}

The expected results were to be input to improve the ability of users/operators in handling IPM and build an understanding related to a culture of caring for maintenance to the top Management of Puskesmas Ciledug.

\section{References}

Alat-alat Elektromedik | Catatan Yusuf Rudiana. (n.d.).

Arillia Pitaloka Kurniasih. (2010). Keselamatan Ketenagalistrikan (K2) - PLN,, my job ${ }^{\wedge}$. Blogspot.

Berkah Mulia Group. (2016). Keselamatan Kerja Pada Kelistrikan - Berkah Mulia Group. Sepatusafetyonline.

DPR RI. (2009). UU RI No. 30 Tahun 2009 KetenagaListrikan (Patent No. 30 Tahun 2009).

Dunia Listrik. (2010). Sistem Tenaga Listrik: Syarat -Syarat Pemasangan Instalasi Rumah/Gedung. Blogspot.Com.

Elektromedik: Macam-Macam Alat Kesehatan bedasarkan jenisnya - Technology And Experiment. (n.d.).

GA. Bassett. (1971). Personal System and Data management. American Management Association Inc.

Hartoyo. (1996). Keselamatan Penggunaan Tenaga Listrik. 
IKATEMI. (2015). Surat Nomor 150 dan 151 tahun 2015.pdf.

Kemenkes, R. (2019). Peraturan Menteri Kesehatan RI No 43 tahun 2019 tentang Puskesmas. Peraturan Menteri Kesehatan RI No 43 Tahun 2019 Tentang Puskesmas, Nomor 65(879), 2004-2006. https://doi.org/10.1093/bioinformatics/btk045

kementerian Kesehatan. (2014). Lampiran Peraturan Menteri Kesehatan Nomor 75 Tahun 2014 Tentang Pusat Kesehatan Masyarakat.

Kesehatan, M., \& Indonesia, R. (2011). Persyaratan Teknis Prasarana Instalasi Elektrikal Rumah Sakit (Patent No. 2306/MENKES/PER/XI/2011).

Margono. (2006). Managemen Pemeliharaan dan Perawatan Mesin. 4(1), 42-48.

Mengenal Klasifikasi dan juga Pengertian Alat Kesehatan | by Alya Savira | Medium. (n.d.).

Ministry of Health, R. of I. (2011). PMK-RI No.2306 tentang Instalasi Elektrikal RS.

Ministry of Health, R. of I. (2019). PMK-RI No.31 2019 Informasi Puskesmas. In Ministry of Health Republic of Indonesia. https://doi.org/10.1145/1390630.1390641

Perbedaan Alat Kesehatan Dan Alat Elektromedik| Biomedical Engineering Elektromedik. (n.d.).

Permenkes. (2016). PMK-RI No.65 Th.2016 Standart Pelayanan Elektromedik.

Rahmad Azly. (2016). Bagaimana cara Menentukan ukuran kabel listrik yang benar Tempat kita berbagi ilmu.

SCORE. (2013). Keselamatan dan Kesehatan Kerja.

Sekretariat Departemen Energi dan Sumber Daya Mineral. (2009). UU Nomor 4 Tahun 2009 tentang Aturan Distribusi Tenaga Listrik.

Swaraswardiyono, C. (2016). Sejarah Pemilihan Tegangan 220 V PLN - Pustaka Swardiyono.

Wikipedia. (2014). Pusat Kesehatan Masyarakat - Wikipedia bahasa Indonesia, ensiklopedia bebas. Wikipedia. 